\title{
Additive manufacturing for COVID-19: devices, materials, prospects, and challenges
}

\author{
Rigoberto Advincula*, Department of Chemical and Biomolecular Engineering and Joint Institute for Advanced Materials, University of Tennessee at \\ Knoxville, Knoxville, TN, USA; Center for Nanophase Materials and Sciences, Oak Ridge National Laboratory, Oak Ridge, TN, USA; Department of Materials \\ Science and Engineering, University of Tennessee at Knoxville, Knoxville, TN, USA \\ John Ryan C. Dizon (D), Additive Manufacturing Research Laboratory, Department of Industrial Engineering, College of Engineering and Architecture, \\ Bataan Peninsula State University, City of Balanga, Bataan 2100, Philippines \\ Qiyi Chen, Center for Nanophase Materials and Sciences, Oak Ridge National Laboratory, Oak Ridge, TN, USA \\ Ivy Niu, Jason Chung, and Lucas Kilpatrick, Department of Chemical and Biomolecular Engineering and Joint Institute for Advanced Materials, \\ University of Tennessee at Knoxville, Knoxville, TN, USA \\ Reagan Newman, Department of Materials Science and Engineering, University of Tennessee at Knoxville, Knoxville, TN, USA \\ Address all correspondence to Rigoberto C. Advincula at radvincu@utk.edu
}

(Received 9 May 2020; accepted 9 July 2020)

\section{Abstract}

The current COVID-19 pandemic has caused the shortage of personal protective equipment (PPE) where improvised manufacturing in particular 3D printing has addressed many needs. This prospective discusses the current global crisis, then follows the wide interest in addressing the shortage of medical devices and PPEs used for treatment and protection against pathogens. An overview of the 3D printing process with polymer materials is given followed by the different 3D printing projects of PPEs and medical devices that emerged for the pandemic (including validation/ testing). The potential for rapid prototyping with different polymer materials and eventual high-throughput production is emphasized.

\section{Introduction about the COVID-19 situation}

The current pandemic and the response by governments worldwide are unprecedented. The severe acute respiratory syndrome coronavirus 2 (SARS-CoV-2) pathogen is a positive-sense single-stranded RNA virus which causes an acute respiratory illness now known as coronavirus disease 2019 (COVID-19). As a "coronavirus", virions (the infective form of the virus) of bulbous surface projections of peplomers (proteins on the surface of the virus) with a net negative charge (carboxy terminus) can have distinct surface adsorption properties including specific transmembrane domain and endodomain assembly effects. It is a pathogenic nanoparticle of about $120 \mathrm{~nm}$ diameter where scientists and epidemiologists are just learning how quickly it spreads and the needs to mitigate exposure. It is still largely unknown how persistent they are in the environment and how they transmit beyond what is known in treating communicable viral diseases in the past. The protection of the frontline healthcare worker is of primary importance. As a result of the worldwide emergency response, there have been many fears of shortages in personal protective equipments

* This author was an editor of this journal during the review and decision stage. For the MRC policy on review and publication of manuscripts authored by editors, please refer to http://www.mrs.org/editor-manuscripts/.
(PPEs) including masks, suits, and face shields, but more importantly critical clinical care equipments such as ventilators, respirators, and other medical devices. These shortages are due to the unpredictable situation of producing or stocking enough supplies to prevent overwhelming the medical system and in providing tests, care, and protection with growing numbers of infected people. The procedures put in place to "flatten the curve" including lockdowns have also produced a tremendous strain in economic activity and has affected the supply chain, exposing the needs for new manufacturing models. To this pandemic, additive manufacturing (AM) has emerged as an alternative and rapid distribution of PPEs and medical devices. This has harnessed volunteerism in many 3D printing focus groups, universities, companies, and others to provide for emergency needs of frontline workers and hospitals. It has also largely emerged that 3D printing of polymer materials and its wide adaptation in PPEs and medical devices including rapid prototyping will play an important role in future responses to a pandemic. A new model has emerged in that design, materials, distributed manufacturing, repairs, and rapid deployment will be used for risk mitigation for many emergency situations.

\section{Medical devices and PPE needs}

First is the focus on the supply chain for the health industry: epidemiology and clinical care. Medical devices that are being used to diagnose, prevent, and treat COVID-19 are 
many including diagnostic tests, ventilators, and PPEs. For testing, the in vitro diagnostic tests are usually conducted on samples such as swabs of mucus taken from the nose or throat, or blood taken from a finger prick. Testing is important to diagnose and get accurate numbers in sampling populations and assessing risks of further spreading. Although many test kits are being developed, the basic tests rely on some types of enzyme-linked immunosorbent assay (ELISA) and polymerase chain reaction (PCR) procedures. Next to consider is a ventilator. This is a medical device used to assist patient breathing (by mechanical or pressure control) by moving breathable air into and out of the lungs with intubation. ${ }^{[1]}$ This is considered a critical care procedure of last resorts and is typically found in intensive care units (ICU)s. On the other hand, the use of PPEs are prevalent, which serves as a barrier between infectious pathogens (e.g., viruses and bacteria) and the nose, eyes, mouth, and the skin. They are needed everywhere especially by frontline workers and are deemed consumables. Contaminants include those from respiratory secretions, body fluids, and blood. Common PPEs used in caring for patients with or under investigation for COVID-19 include isolation gowns, N95 respirators/masks, face shields/eye protection, and gloves. ${ }^{[1,2]}$ In fact, there are many other critical needs including sterilizable devices, ventilator disposables, and sample collectors that are still emerging. More importantly, these devices and test kits must first be approved by the Food and Drug Administration (FDA) before usage.

\section{Devices, components, and materials Diagnostic test kits}

Diagnostic tests for the coronavirus include reverse transcription PCR (RT-PCR), reverse transcription loop-mediated isothermal amplification (RT-LAMP), and real-time RT-PCR (rRT-PCR) ${ }^{[3,4]}$ Computerized tomography of a patient's chest is used to assess the severity of the disease (COVID-19) through imaging. ${ }^{[5]}$ Discussions on these laboratory techniques are not covered in this review nor are the different test kits; however, the material used for nasopharyngeal/oropharyngeal test swabs which is being used to obtain samples will be briefly discussed. ${ }^{[5]}$ For the test swabs, usually, a polyester swab with a plastic shaft is being used. ${ }^{[6]}$ Other materials used as swabs include polymers commercially known as Rayon and Dacron, a cellulose and polyester polymer, respectively. ${ }^{[7]}$ It will be evident that manufacturing of these test kits will rely on FDA-approved polymers or plastics that are also 3D printable.

\section{Ventilators}

Ventilators are a critical piece of equipment for patients suffering from COVID-19. It is estimated that about $5 \%$ of all patients with COVID-19 will require a ventilator to support their respiration while recovering from the severe lung disease. ${ }^{[8]}$ It is critical for healthcare facilities to have a sufficient number of ventilators because access to such equipment directly affects the number of deaths associated with the disease in an ICU. An understanding of the operation of ventilators as they relate to the symptoms of
COVID-19 are paramount as faulty design and operation can lead to unintended consequences including lung failure. To put it simply, a critically ill patient is unable to breath on their own. The mechanical ventilator supports the patient's respiration by providing positive pressure to the lungs. During inhalation, the ventilator provides tidal volume for a set amount of time. During exhalation, the positive pressure is removed and the patient exhales passively. This sequence repeats for a specified number of breaths per minute. Mechanical ventilation can be administered noninvasively using masks or helmets or invasively using endotracheal tubes (intubation). In the USA, noninvasive ventilation is not recommended for patients with COVID-19 due to the high risk of aerosolization and the rapid rate of respiratory deterioration. ${ }^{[8]}$

Figure 1 shows the main components of a mechanical ventilator which are mainly the power source, controls, monitors, safety features, and auxiliary components. ${ }^{[9,10]}$

\section{Personal protective equipment Face shields}

Most face and eye PPEs being used in the USA are designed, tested, and manufactured according to the American National Standards Institute (ANSI) Z.87.1-2010 standard. ${ }^{[1,12]}$ Face shields usually have the following components: frame, visor, and suspension. Materials for commonly used PPEs for COVID-19 are summarized in Table I. Supplementary Figure $\mathrm{S} 1$ shows the minimum specifications in urgent manufacturing of face shields. ${ }^{[13]}$

- Frame: This is the part which holds the visors, and also fits the face shield onto the head of the health personnel. There are adjustable and nonadjustable frames, metal clip-on frames, and detachable frames.

- Visor: This is also known as the window/lens. Visors may also be coated to impart ultraviolet light (UV) protection, antistatic, antiglare, and antifogging properties, as well as scratch resistance features to extend its life. ${ }^{[11,19]}$

- Suspension system: These are plastic materials which could have a pin-lock system, ratchet mechanism or Velcro®. Elastic straps may be used for nonadjustable systems. Some models have temple bars, nose pads, and bridge assemblies in order to maintain correct the face shield position. Other models have bands for added support and depth adjustment.

\section{Respirators}

Respiratory protection is needed during aerosol-generating procedures and for isolation precautions for routine care during viral outbreak. In such cases, respirators are usually needed as protective equipment. ${ }^{[20]}$ Respirators are PPEs worn on the face which usually cover the mouth and nose, and are used to reduce the health professional's risk of inhaling hazardous airborne particles (including vapors, gases, infectious agents, or dust). ${ }^{[14]}$ Air-purifying respirators (APRs) uses filters, canisters, or cartridges in removing aerosols, vapors, gases, or a combination of contaminants from the air. They do not supply oxygen. 


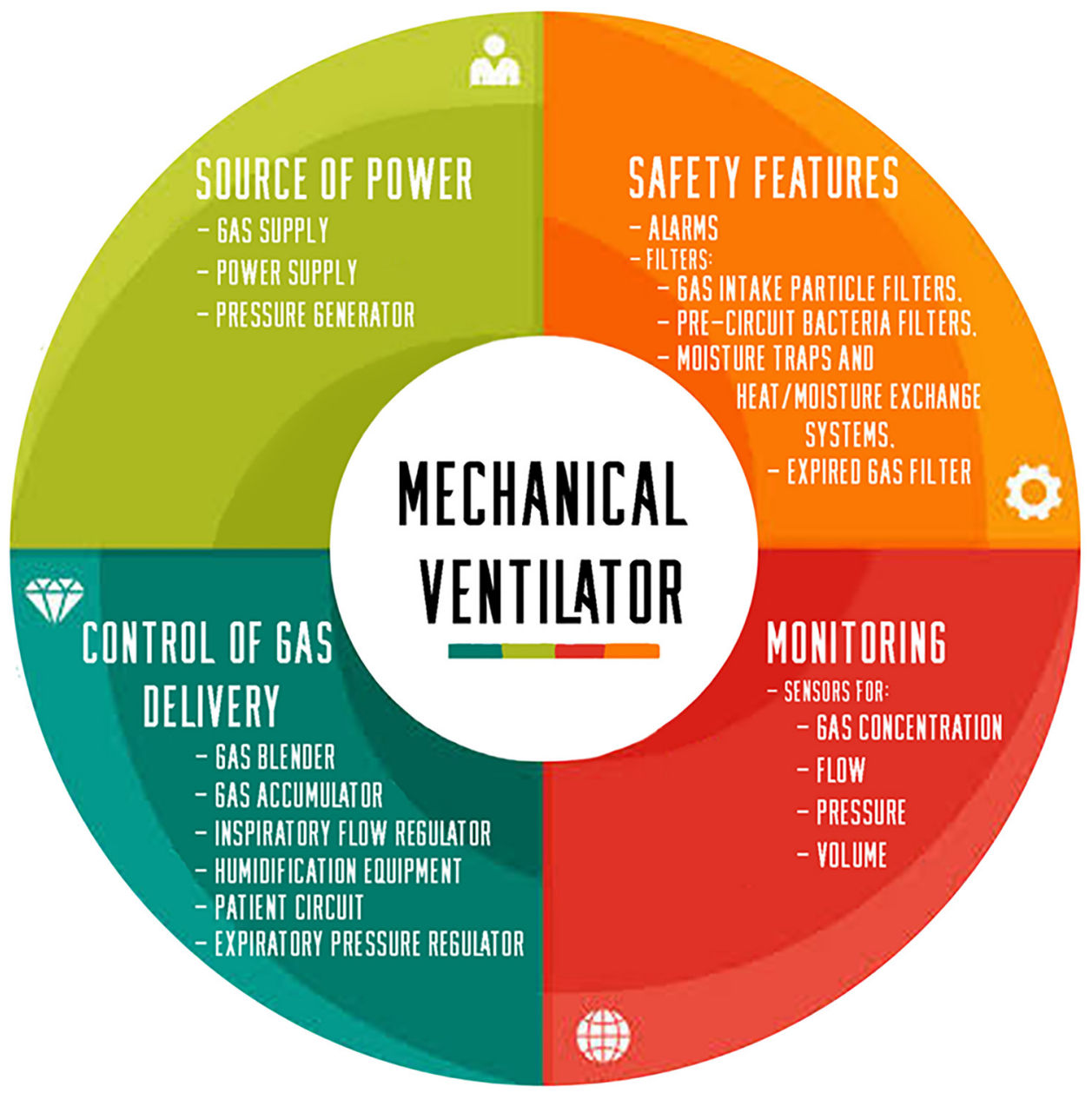

Figure 1. Essential parts of a mechanical ventilator.

Table I. Materials for common PPEs used to protect against COVID-19.

\begin{tabular}{|c|c|c|c|}
\hline PPE & $\begin{array}{l}\text { Parts/components/ } \\
\text { types }\end{array}$ & Materials used & Ref. \\
\hline \multirow[t]{3}{*}{ Face shield } & Frame & Lightweight plastic & {$[11]$} \\
\hline & Visor & Polycarbonate, propionate, acetate, PVC, and polyethylene terephthalate glycol (PETG) & {$[11]$} \\
\hline & Suspension & Plastic materials for adjustable headbands & [11] \\
\hline N95 Respirator & Filter & $\begin{array}{l}\text { Internal and external layers: spun-bonded PPPre-filtration layer: needled nonwovenFiltration } \\
\text { layer: meltblown electret (or polarized) nonwoven material }\end{array}$ & {$[14,15]$} \\
\hline Surgical mask & Filter & $\begin{array}{l}\text { Nonwoven PP } 20 \text { gsm: spun-bonded process } 25 \text { gsm: meltblown technologyOther materials: } \\
\text { polyester, PC, polystyrene, or PE }\end{array}$ & {$[16]$} \\
\hline \multirow[t]{2}{*}{ Isolation gown } & $\begin{array}{l}\text { Reusable isolation } \\
\text { gown }\end{array}$ & Kona cotton, polyesterpolyester-cotton blends & {$[17]$} \\
\hline & $\begin{array}{l}\text { Disposable isolation } \\
\text { gown }\end{array}$ & PP, polyester, PE (be thermal, chemical, or mechanical seaming) & {$[17]$} \\
\hline $\begin{array}{l}\text { Protective } \\
\text { footwear }\end{array}$ & Insole & PP, PC, PA (meltblown and nonwoven) & {$[18]$} \\
\hline
\end{tabular}


APRs have several types: (i) Filtering Facepiece Respirator (FFR), the most common of which is the N95 respirator; (ii) Elastomeric Half Piece Respirator; (iii) Elastomeric Full Facepiece Respirator; (iv) Powered Air-Purifying Respirator (PAPR); and (v) Powered Air-Purifying Respirator (airsupplying). Air-filtering respirators prevent bacteria and other contaminants from reaching the mouth and nose. Air-supplying respirators on the other hand provide clean air to the user (health professional) usually from a tank or other uncontaminated source. ${ }^{[21]}$ Supplementary Table SI summarizes the different types of APRs. ${ }^{[22,23]}$

The following discussions focus on the N95 respirator and the PAPR which are usually used against pathogens. A commercially available N95-type respirator would usually have a pliable (usually aluminum) nosepiece to allow the user to adjust the fit at the nose. ${ }^{[14]}$ Another type of respirator aside from the N95 respirator is the PAPR. A PAPR provides filtered air (providing positive air flow) to users in a hazardous environment. It is a device which covers the whole head of the health professional and uses a battery-powered blower providing airflow through a filter to the hood or face piece. The type of filter is dictated by the type and amount of airborne contaminant. ${ }^{[20]}$ PAPRs only function in ambient environments, i.e., they do not supply air in a low-oxygen environment. ${ }^{[21]}$ Essential parts of a PAPR include the cartridge/canister for filter, blower, tubing, head gear/hood, and batteries. ${ }^{[24]}$ Supplementary Figure S2(b) shows an example of a PAPR.

\section{Surgical masks}

Surgical masks prevent pathogens from the mouth and nose of a health worker from contaminating a patient during surgery. Surgical masks are not effective in filtering out viruses (as viruses are smaller than bacterial pathogens). There are several classifications of surgical masks (i.e., four levels of ASTM certification) which depends on the level of protection they provide the wearer, namely, Minimum protection, Level 1, Level 2, and Level 3. Level 3 is used for heavy exposure to aerosol, spray, and fluid. Masks are tested for the following: bacteria filtration efficiency (BFE) in vitro, particle filtration efficiency, breathing resistance, splash resistance, and flammability. ${ }^{[16]}$ Surgical face masks are usually made with nonwoven polypropylene (PP) fabric, with 20-25 grams per square meter (gsm) in density. The 20 -gsm fabric is produced via a spunbond process. In the spunbond process, the melted plastic material is extruded in a web (on a conveyor), where strands bond with each other upon cooling. The 25 -gsm mask material is produced via meltblown technology. In this process, the plastic is extruded through a die with hundreds of small nozzles. The material is then blown by hot air to become tiny fibers. Cooling and binding on a conveyor follows. The diameters of these fibers are less than $1 \mu \mathrm{m}$. Nonwoven (disposable) surgical masks are made with three or four layers, usually covering both sides of a layer of textile with nonwoven-bonded fabric (as filter layers). These filter layers are effective at filtering out particles above 1 $\mu \mathrm{m}$. The level of filtration of a mask depends on several factors, namely, the way the fiber is manufactured, the structure of the resulting web, and cross-sectional shape of the fiber. In manufacturing masks, initially, the nonwoven material is assembled from bobbins, the different layers of the mask are then ultrasonically welded, and then the other parts such as the nose strips and ear loops are stamped. The masks are sterilized before packaging and shipping. ${ }^{[16]}$

\section{Protective gowns}

Healthcare workers need these gowns from picking up transmissible diseases from patients, and these are classified by the FDA into nonsurgical, surgical, and surgical isolation gowns. Nonsurgical isolation gowns are used to protect wearers from the transfer of body fluids and microorganisms in low or minimal risk patient isolation situations. ${ }^{[17]}$ They can be based on woven and nonwoven fabrics. They can also be considered reusable (sterilizable) or disposable, respectively. Woven fabrics or textiles are mostly made from polyesters and are washable. Nonwovenbased fabrics are mostly meltblown polyethylene (PE), PP, polyamides (PAs), and polycarbonate (PC). It is to be noted that protective gowns, bonnets, and shoe covers are common clean room supplies as well and are widely available until recently.

\section{Protective footwear}

For complete protection of the healthcare professional, a protective footwear is needed. Footwear should have a closed back, closed-toe, soft-soled, and washable. For the insoles, meltblown nonwoven PP, PC, or PA is usually used. ${ }^{[18]}$

\section{Overview of AM $A M$ introduction}

AM, commonly called 3D printing, is an advanced fabrication method in which three-dimensional objects are created by depositing the material in a series of successive thin layers. ${ }^{[25]}$ Figure 2(a) illustrates the major steps of AM. The 3D printing workflow typically begins with a three-dimensional computeraided design (CAD) model of a part. The solid CAD model is converted to a polyhedral representation of the part, usually in the STL, OBJ, or AMF file type. ${ }^{[26]}$ This 3D file is loaded into a software called a "slicer," which accepts parameters from the user and "slices" the file into a series of layers. The slicer then generates a set of numerical instructions for building each layer in successive order and stores them in a file type, usually called G-code, that is readable by the 3D printer's microcontroller. ${ }^{[27,28]}$ The $3 \mathrm{D}$ printer follows the G-code instructions and builds the part by adding the material one layer at a time. When the print is completed, the user may perform post-processing operations, such as removing the support material, curing, heat treating, and cleaning. ${ }^{[25]}$ Common AM technologies are shown in Fig. 2(b). 3D printers may be classified by their mode of operation. Some of the most common 3D printing technologies are summarized in Table II. Supplementary Figure S3 illustrates the fuse deposition modelling, which is the most common $3 \mathrm{D}$ printing technology. ${ }^{[29]}$ 
3D Printing workflow
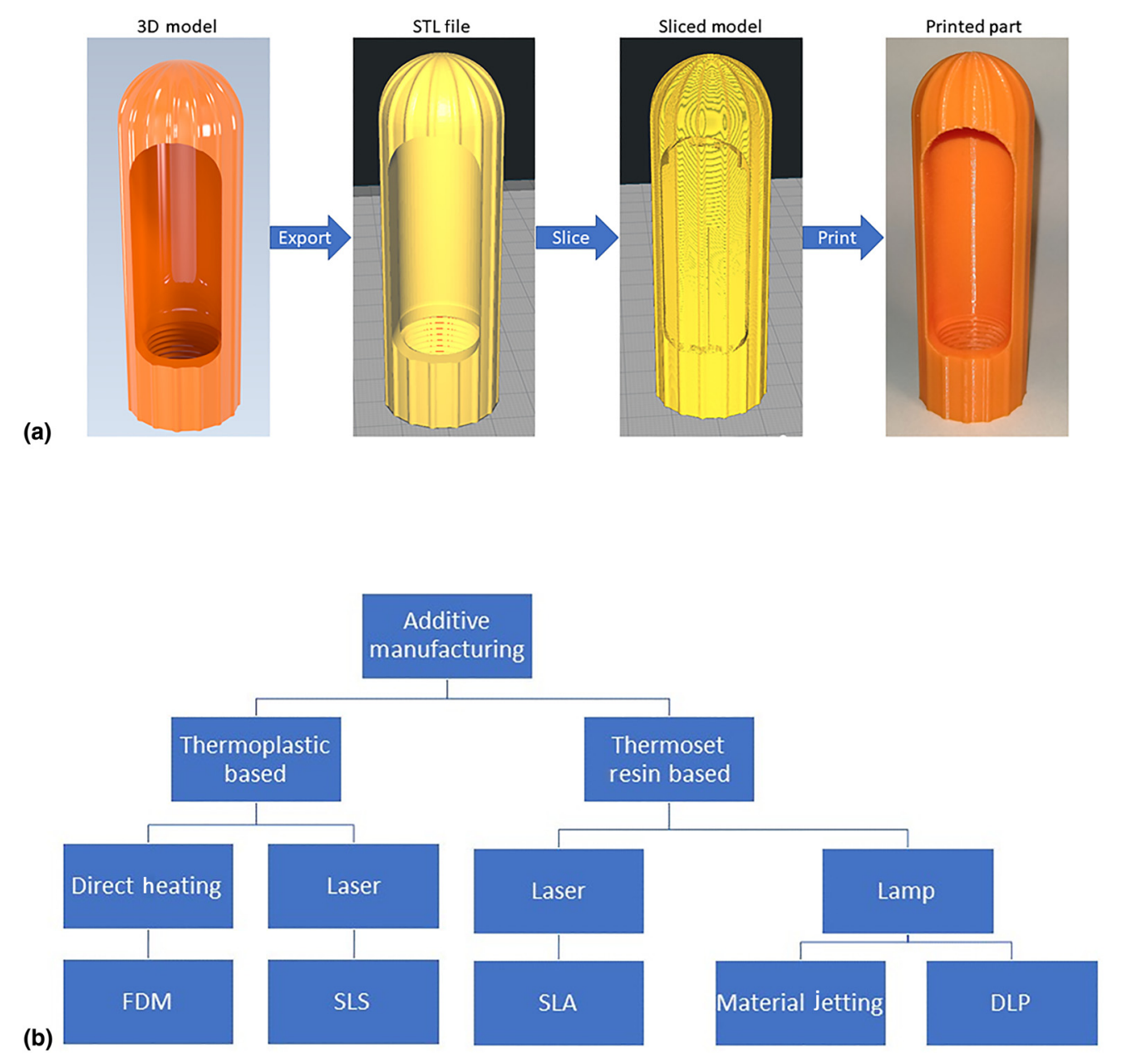

Figure 2. (a) Stages of the 3D printing process without post-processing and (b) common AM technologies.

$3 \mathrm{D}$ printing enables the manufacture of geometrically complex parts with little added complexity to the user. ${ }^{[35]}$ Among AM's core uses are short run production, rapid prototyping, experimental material research, injection mold making or tooling, and product visualization. AM produces significantly less waste than traditional subtractive manufacturing methods, such as computer numerically controlled machining. ${ }^{[25,28]}$ Recently, 3D printing has been used in advanced applications to create biocompatible medical devices, silicone foams with tunable elastic properties, high-performance composite materials, and highly efficient salt water desalination membranes. ${ }^{[27,30,34-36]}$

\section{Categories of projects in 3D printing and current groups engaged in 3D printing activities for COVID-19 Current projects on PPE}

As the COVID-19 pandemic spread rapidly worldwide, PPEs are in great shortage with increasing demand, especially in isolated communities. While the transportation and logistics around the world slowed down, the advantage of "on-demand" and local production (or what is called distributed manufacturing) enable $3 \mathrm{D}$ printing as a means of providing more PPEs without relying on the normal supply distribution chain. Many companies, universities, and research centers in the 3D printing community are contributing to the design and production of different types of PPE locally. These include reusable respirator/protective facial mask to tackle the deficiency of N95 mask, facial shield to give extra protection of essential workers, and hands-free door-open accessories to open the door using arms instead of the hand. Likewise, there are other small parts produced by rapid prototyping 3D printing such as the attachment on masks or goggles for a better fit, 3D-printed human head models to test the seal function of the masks or goggles. During the course of writing this review, more and more contributions from companies, universities, and research centers will be released with new and updated designs. Most of these designs and .stl files are also open source and could be downloaded from the links provided in 
Table II. Operating principles of some common 3D printing technologies. ${ }^{[25,27,30-32]}$

\begin{tabular}{|c|c|}
\hline Name & Description \\
\hline $\begin{array}{l}\text { FDM or Fused Filament } \\
\text { Fabrication (FFF) }\end{array}$ & $\begin{array}{l}\text { Thermoplastic filament is melted and } \\
\text { extruded into lines that fuse together to } \\
\text { form layers. Some FDM printers can use } \\
\text { polymer pellets instead of filament, } \\
\text { which reduces material costs. FDM } \\
\text { printing is the most common form of } \\
\text { AM due to its low material and machine } \\
\text { cost, and simple operation. }{ }^{25]}\end{array}$ \\
\hline SLA & $\begin{array}{l}\text { A thin film of liquid photopolymer resin is } \\
\text { selectively solidified by a numerically } \\
\text { controlled UV laser scanning system. } \\
\text { SLA offers very high resolution and is } \\
\text { the oldest 3D printing } \\
\text { technology. }{ }^{[27,28,33]}\end{array}$ \\
\hline $\begin{array}{l}\text { Digital light processing } \\
\text { (DLP) }\end{array}$ & $\begin{array}{l}\text { A thin film of liquid photopolymer resin is } \\
\text { selectively solidified by a shaped light } \\
\text { projection. }{ }^{[25]} \text { DLP does not offer } \\
\text { resolution as high as SLA, but DLP } \\
\text { machines are much less expensive than } \\
\text { SLA machines. }\end{array}$ \\
\hline $\begin{array}{l}\text { Selective laser } \\
\quad \text { sintering (SLS) }\end{array}$ & $\begin{array}{l}\text { A layer of powder is selectively melted by a } \\
\text { laser numerically controlled laser } \\
\text { scanning system. }{ }^{[34]} \text { SLS printers can } \\
\text { work with metal or polymer powders, } \\
\text { depending on the power of the laser. }\end{array}$ \\
\hline Material Jetting (MJ) & $\begin{array}{l}\text { Tiny droplets of UV-cure photopolymer } \\
\text { resin are ejected from the printhead onto } \\
\text { a build plate or into a layer of powder } \\
\text { where they are instantly cured under a } \\
\text { UV lamp. }{ }^{[25]}\end{array}$ \\
\hline
\end{tabular}

Supplementary Table SII. The U.S. Department of Health and Human services - National Institute of Allergy and Infectious Diseases led and created the NIH 3D Print Exchange website, where hundreds of 3D-printed medical models including PPE designs are available. The FDA has released guidelines for 3D printing relief items and directs readers to a NIH website which is functioning as an exchange for 3D printable files and information. ${ }^{[37,38]}$

Among the different PPEs, the APR is one of the most effective equipment to decrease the spread of airborne virus. Lots of efforts from the 3D printing community has responded to producing reusable protective masks. Different designs of printing mask .stl files were released as open resource to the community. Current efforts on 3D printing reusable protective mask from worldwide organizations are summarized in Table III. Aside from the listed projects here, many projects are being done by individuals and teams on websites as summarized in Supplementary Table SII. Each of these designs include a sealed cup-shaped part along the lower face, as well as a removable cartridge and cap to sit the filtration unit. While different printing materials including polymer filament and sintering polymer powder were chosen for the mask, different $3 \mathrm{D}$
Table III. Projects on 3D printed reusable respirator/protective facial mask to tackle the deficiency of N95 mask.

\begin{tabular}{llll}
\hline $\begin{array}{l}\text { Organization/model } \\
\begin{array}{l}\text { VHA/Stopgap Face } \\
\text { Mask }\end{array}\end{array}$ & $\begin{array}{l}\text { Printing } \\
\text { material }\end{array}$ & $\begin{array}{l}\text { Printing } \\
\text { method }\end{array}$ & Ref. \\
\hline $\begin{array}{l}\text { Make The Masks/ } \\
\text { MONTANA }\end{array}$ & PLA & SLS & {$[39]$} \\
\hline $\begin{array}{l}\text { Medical University of } \\
\text { South Carolina/ } \\
\text { HEPA Mask }\end{array}$ & PLA & FDM & {$[40]$} \\
\hline $\begin{array}{l}\text { Barrow Neurological } \\
\text { Institute }\end{array}$ & PLA & FDM & {$[41]$} \\
\hline $\begin{array}{l}\text { Rowan University } \\
\text { WASP }\end{array}$ & PLA & FDM & {$[42]$} \\
\hline $\begin{array}{l}\text { George Washington } \\
\text { University }\end{array}$ & PCL & FDM & {$[43]$} \\
\hline $\begin{array}{l}\text { Copper 3D/NanoHack } \\
\text { 2.0 }\end{array}$ & Antibacterial & FDM & {$[44]$} \\
\hline $\begin{array}{l}\text { HP and Czech } \\
\text { Technical } \\
\text { University/CIIRC } \\
\text { RP95 }\end{array}$ & PLACTIVE & FDM & {$[45]$} \\
\hline $\begin{array}{l}\text { Brno University of } \\
\text { Technology/ } \\
\text { HUT-H1 }\end{array}$ & PLA and ABS & FDM & {$[48]$} \\
\hline
\end{tabular}

printing methods were involved including fused deposition modeling (FDM), stereolithography (SLA) and multi-jet fusion (MJF). The FDM printing method has minimal requirement on the printing materials, and the most popular filaments used are polylactic acid (PLA) and acrylonitrile butadiene styrene (ABS) due to their wide availability in 3D printing labs. For example, Provenzano et al. from George Washington University selected several designs from the open resource and used PLA and ABS filament for FDM 3D printing. They evaluated the printability, leakage, and fitting performance of each model and further improved the model based on seal, comfort, and sizing. ${ }^{[45]}$ The Copper 3D company, which produce antibacterial 3D printing filament, developed their own model NANOHACK 2.0 based on FDM 3D printing. They employed their own antibacterial PLACTIVEC filament, which is a FDA-registered material that could eliminate more than $99.99 \%$ of fungi, viruses, and bacteria. ${ }^{[46]}$ Burget and coworkers from Czech Technical University developed their own prototype of protective mask using an HP Multijet Fusion printer, which sinters polyamide (PA) powders in contrast to melting polymer filaments. They achieved the production efficiency of approximately 70-100 pieces/day per equipment. They also specify that the printed parts possess more compact structures compared with FDM printing, which are much impermeable to virus and microorganisms. ${ }^{[47]}$ 
All of these 3D-printed masks require inserting a filter. Filter materials employed in current medical and N95 mask are electrostatic nonwoven PP fibers which are produced by melt blowing. The modification used high-grade filters that has been applied in heating, ventilation, and air conditioning such as air conditioner and vacuum cleaner bags. ${ }^{[4]}$ American Society of Heating, Refrigerating and Air-Conditioning Engineers (ASHRAE) use the Minimum Efficiency Reporting Value (MERV) to report the effectiveness of air filters. The MERV is from 1 to 16 and derived from the efficiency of filtration. MERVs 13-16 are efficient to filtrate bacteria, droplet nuclei (sneeze), smoke and insecticide dust, and face powder, with the minimal particle size of $1.0-0.3 \mu \mathrm{m}$. Provenzano et al. used both MERV 13 and MERV 16 in their research as they pointed out some of the MERV 16 sheet might contain glass fiber which is considered as potential health hazard. ${ }^{[45]}$ Another idea is using the N95 mask itself as filter materials, the reduced area of the 3D-printed mask, greatly decrease the use of filter materials and could turn one N95 mask to several masks.

Face shields, used to protect medical workers' facial areas from macroscopic airborne particles and fluids, are also one of the most popular products being produced by the 3D printing community. ${ }^{[11]}$ The relatively simple geometry and nonstrict material requirements of 3D-printed face shields enable manufacturing using entry-level FDM machines. Other popular articles manufactured by FDM include face masks, hands-free door openers, and protective eyewear. Several prominent FDM machine manufacturers, including Prusa Research and Creality, have released 3D files and instructions for the manufacture of such items. ${ }^{[50,51]}$

\section{Mechanical devices}

Many hospitals around the world do not have enough equipment in their facilities to accommodate all of their patients for COVID-19. Because of this shortage, many companies and universities are using $3 \mathrm{D}$ printing to provide the equipment and parts that hospitals need, particularly ventilators. Figure 3 shows 3D-printed devices and facilities to address the needs during the COVID-19 pandemic. Many organizations are already developing new ways to manufacture ventilators such as the Oxford University OxVent, ${ }^{[52]}$ Mechanical Ventilator Milano, ${ }^{[53]}$ and MIT Mechanical Ventilator ${ }^{[54]}$ just to name a few. These designs are low cost, freely available online, and are meant to be mass produced in case of an emergency. The low cost of these three ventilators come from their use of off-the-shelf components and manual bag valves commonly found in medical facilities. The current practice for the bag valves requires manual operation during patient transport. However, there is some concern with these designs because critically ill COVID-19 patients usually require intubation which these designs do not support. Perhaps, other designs such as VentilAid ${ }^{[5]}$ and E-Vent ${ }^{[56]}$ are more favored due to their simplicity and manufacturability. The ventilator design challenge has even reached automotive companies. Tesla is (a)

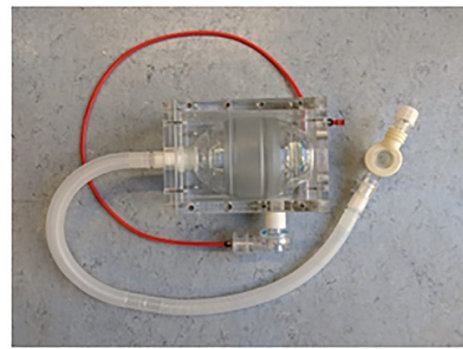

(b)

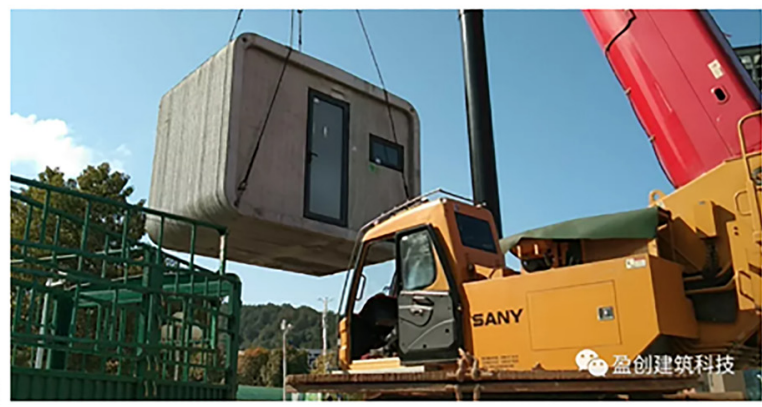

(c)

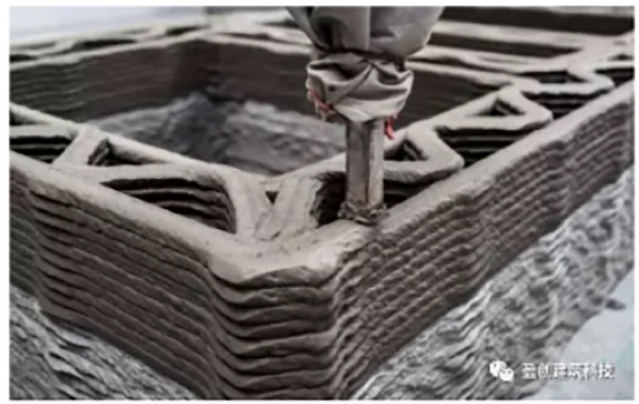

Figure 3. 3D-printed devices and facilities for COVID-19: (a) The OxVent; (b) a completed ward being transferred to a new location; and (c) a close up of the 3D-printed interior structure.

designing a ventilator using spare parts from their Model $3,{ }^{[57]}$ and many other automakers, like Volkswagen, have claimed to begin manufacturing ventilators as well. ${ }^{[58]}$ Many groups are also helping with replacement parts to the existing equipment. Isinnova, an Italian engineering firm, 3D-printed replacement oxygen valves for a local hospital. Another Italian company, CRP Technology, manufactured emergency valves for assisted ventilation. ${ }^{[58]}$ Johns Hopkins University has designed a ventilator splitter to allow ventilators to be shared with multiple patients, ${ }^{[59]}$ and a similar ventilator splitter has been produced by Prisma Health, a health organization in South Carolina ${ }^{[58]}$ Many of the designs made by these companies are "free use," so that anyone around the world can print their design and help their communities. While potentially useful, many are concerned about the use of ventilator splitters. Splitting the air flow between multiple patients will not guarantee each patient will receive adequate amounts of air. Also, the defects that can come with 3D-printed models may lead to high risks of cross-contamination. 
On a construction scale, WinSun, a Chinese construction 3D printing company, is creating isolation wards to house medical staff. Each isolation ward is $10 \mathrm{~m}^{2}$ and has a height of 2.8 $\mathrm{m}$. These structures are 3D-printed using concrete and recycled materials. One of the biggest benefits to these isolation wards are their mobility. According to WinSun, the wards are easy to transport and can easily be connected to a power supply. The company is currently looking for resources to complete the wards such as solar panels, doors, and windows. ${ }^{[60]}$

\section{Testing/treatment}

More complex items, or items with stricter material requirements, are being produced by SLA, DLP, and other highresolution AM technologies. ${ }^{[61]}$ Nasopharyngeal swabs (nasal swabs), used to collect a sample of a patient's mucus for analytical testing, are being produced in large batches by resin printing companies FormLabs and Carbon. ${ }^{[62,63]}$ Other types of test kits, disposables, sample collectors with better designs for in vitro testing, or point-of-care devices should appear over time. 3D printing can lead the way in producing these prototypes and materials testing.

\section{Types and properties of polymer and plastic materials commonly used for mass production of parts}

Polymer materials can be classified into three major categories: thermoplastics, elastomers, and thermosets. ${ }^{[64]}$ Thermoplastics are mostly composed of linear molecular chains, and the interactions between individual chains are physical interactions, such as Van der Waals force and hydrogen bonding. Typical thermoplastic polymers are PE, PP, polyamides (PA), PLA, and PVC. The physical interaction between linear chains can be broken by heat or solvent, which allows the thermoplastic to be processed by melting or dissolving. ${ }^{[65]}$ Traditional heat processing includes injection molding, blow molding, and compression molding where polymers are heated above its melting temperature to become liquified, followed by pressurizing into a mold and solidifies by cooling. The shapes of thermoplastic products are determined by the geometry of the mold. Solution processing is also used for thermoplastic, especially in thin film fabrication, where polymers are dissolved in an appropriate solvent, deposited onto targeted surfaces, and the polymers will solidify upon the drying of the solvent. Both heat and solution processing are employed in $3 \mathrm{D}$ printing of thermoplastics. FDM, ${ }^{[36,66]}$ one of the most dominant 3D printing technique, is based on the melt-extrusion-deposition process of thermoplastics, as shown in Supplementary Fig. S3. Instead of shaping polymer into molds, 3D printing builds polymer in a mold-free process in which architectures are generated via a layer-by-layer stacking manner. Direct ink writing (DIW) or viscous solution printing has been recently used to 3D print thermoplastic polymers in solution. To maintain the 3D shape of polymer solutions, the rheological properties and solvent evaporation rate need to be properly modified. ${ }^{[35,67]} \mathrm{A}$ thermoset polymer is composed of molecular networks in which polymer chains are connected together by covalent bonds (chemically). Gels and pastes can be crosslinked by noncovalent bonds (physical interactions). Therefore, thermosets cannot be melted or dissolved due to the strong covalent crosslinking interaction. Processing of a thermoset is normally conducted by injecting unreacted or partially reacted precursors into a mold, followed by complete crosslinking inside the mold ${ }^{[64,65]}$ and also requiring the material to be thixotropic. $3 \mathrm{D}$ printing of thermosets also starts with the liquid precursor. Depending on the crosslinking mechanism, different techniques are applied. UV-cured thermosets, such as acrylate-based resin, are normally printed by SLA, while thermally cured thermosets are mostly printed by DIW. ${ }^{[33,68]}$ Elastomers can be further classified as thermoplastic elastomers or thermoset elastomers which describe their origin or similarity in properties to the two other classes of polymers.

The important classes of polymers that can be used for $3 \mathrm{D}$ printing are also important for formative manufacturing, i.e., injection molding and thermoforming. While most common consumer devices such as automotive parts and appliances use these polymers, they are also common in typical PPEs, medical devices, and clinical disposable supplies. Therefore, it is necessary to have an appreciation of some of these polymers. A more detailed discussion of these polymers are in the Supplementary Material document but briefly they are introduced as follows ${ }^{[69-76]}$ :

- PE is the most commonly produced synthetic polymer and can be classified as LDPE, LLDPE, HDPE, and UHMWPE, depending on the molecular weight and degree of branching - hence crystallinity.

- PP has many similar properties as PE, especially in solubility and electrical properties. It can have various tacticities and higher crystallinity. It has low strength and hardness, but high ductility and toughness. In general, it has better thermomechanical properties and chemical resistance.

- PVC: When the methyl group of PP is replaced by chloride, it gives very different properties than PP or PE. It has very high hardness, rigidity and mechanical strength, and excellent chemical resistance to acid, base, and salts. To process these materials, heavy plasticization including phthalates is required.

- Polyamide (PA), also called nylon, is a family of synthetic polymers with repeating units linked by amide groups. PA is normally produced by the condensation reaction. It can also be produced by the self-reaction of amino acid or ringopening polymerization of lactam, producing a mono repeating unit. The amide group (--CO-NH) is highly polar and forms intermolecular hydrogen bonds which facilitates the crystallization of PAs, thus offering excellent mechanical strength and chemical resistance.

- $\mathrm{PC}$ is a thermoplastic family containing carbonate groups in the backbone. Most PC is produced by bisphenol A (BPA)-based precursor. The carbonate group (-O-CO-O-) 
confers high rigidity, and the BPA structure exhibits excellent impact resistance, durability, and high temperature resistance.

- PLA is a thermoplastic polyester, which draws great attention recently due to its derivation from renewable resources and biodegradability. It is produced from ring-opening polymerization of lactide, a monomer that has abundant renewable feedstocks.

- Polyurethane (PU) is a class of polymers with repeating units linked by urethane groups additively, which is produced by the reaction between isocyanate and hydroxyl groups. PU can be divided into two categories: crosslinked PU and thermoplastic PU (TPU). TPU is one of the most important elastomeric polymers. It consists of alternating hard segments in which short rigid structures form crystalline domain, and soft segments in which long soft chains generate amorphous domain.

- Silicone also called polysiloxane, refers to polymers that contain siloxane group, consists of alternating silicon and oxygen atoms. The siloxane chains exhibit excellent heat resistance, low thermal conductivity, low electrical conductivity, low toxicity, and high hydrophobicity. When the siloxane groups are crosslinked into a network, silicone becomes a highly elastic rubber with superb properties.

\section{Importance of validation and testing Validation and testing-ASTM standard}

There are a number of testing and certification standards that can be used for validating the properties of materials used in the medical industry. The materials properties, application protocols, and fatigue or failure in performance can be ascertained by International Standards Organization (ISO), United Laboratories (UL), and American Society for Testing and Materials (ASTM) standards. For clinical use, the FDA standard has the final word for certifying the application with contact to the human body. Specific challenges in applying these standards to 3D-printed polymer parts can be addressed by fist evaluating with existing monolith materials standards (ASTM, ISO, and EN) and then differentiating the directionality of the additive layering process including the role of post-printing curing or annealing. Reliability and sterility in clinical settings will be important and is a role fulfilled by the FDA approval process.

As an example, the ASTM standards for testing medical grade facial mask include ASTM F2299/F2299M-03 for determining the initial efficiency of filter materials. It employs monodispersed aerosols in the testing procedure to measure the filtration efficiency by comparing the particle count in the feed stream to that in the downstream after filtrate. ${ }^{[77]}$ ASTM standard F210119 is standard method for testing the bacterial filtration efficiency (BFE) of medical face mask materials using biological aerosol of Staphylococcus aureus. It is aimed to evaluate the material itself, not the ergonomics design and fit of the mask. ${ }^{[78]}$ ASTM standard F1863/F1862M-17 is the method to testing the resistance of medical mask to penetration by biological liquid — synthetic blood. ${ }^{[79]}$ ASTM F2100 - 19 is a specification which covers the performance of materials used in medical face mask including BFE,
Table IV. Summary of current projects relating to medical devices and associated components to aid in the COVID-19 pandemic.

\begin{tabular}{|c|c|c|c|}
\hline $\begin{array}{l}\text { Medical } \\
\text { device }\end{array}$ & Organization/model & Materials used & Ref. \\
\hline \multirow[t]{6}{*}{$\begin{array}{l}\text { Mechanical } \\
\text { ventilator }\end{array}$} & $\begin{array}{l}\text { Oxford University/ } \\
\text { Oxvent }\end{array}$ & $\begin{array}{l}\text { Off-the-shelf } \\
\text { components/Bag } \\
\text { Valve/3D-printed } \\
\text { components }\end{array}$ & [52] \\
\hline & $\begin{array}{l}\text { Mechanical } \\
\quad \text { Ventilator Milano }\end{array}$ & $\begin{array}{l}\text { Off-the-shelf } \\
\text { components/ } \\
\text { Pneumatic } \\
\text { Valves/ } \\
\text { 3D-printed } \\
\text { components }\end{array}$ & [53] \\
\hline & $\begin{array}{l}\text { MIT/Mechanical } \\
\text { Ventilator }\end{array}$ & $\begin{array}{l}\text { Off-the-shelf } \\
\text { components/ } \\
\text { Bag-valve Mask/ } \\
\text { 3D-printed } \\
\text { components }\end{array}$ & [54] \\
\hline & VentilAid & $\begin{array}{l}\text { 3D-printed } \\
\text { components/ } \\
\text { Pneumatic } \\
\text { Actuator }\end{array}$ & [55] \\
\hline & MIT/E-Vent & $\begin{array}{l}\text { Off-the-shelf } \\
\text { components/Bag } \\
\text { Valve/3D-printed } \\
\text { components }\end{array}$ & [56] \\
\hline & Tesla & $\begin{array}{l}\text { Tesla Model } 3 \\
\text { Electronics/ } \\
\text { Suspension Air } \\
\text { Tank }\end{array}$ & [57] \\
\hline \multirow[t]{2}{*}{$\begin{array}{r}\text { Ventilator } \\
\text { splitter }\end{array}$} & $\begin{array}{l}\text { Johns Hopkins } \\
\text { University }\end{array}$ & $\begin{array}{l}\text { 3D-printed } \\
\text { component }\end{array}$ & [59] \\
\hline & $\begin{array}{l}\text { Prisma Health/ } \\
\text { VESper }\end{array}$ & $\begin{array}{l}\text { 3D-printed } \\
\text { component }\end{array}$ & [58] \\
\hline Oxygen valve & Isinnova & $\begin{array}{l}\text { 3D-printed } \\
\text { component }\end{array}$ & [58] \\
\hline $\begin{array}{l}\text { Isolation } \\
\text { wards }\end{array}$ & WinSun & $\begin{array}{l}\text { Concrete/recycled } \\
\text { materials }\end{array}$ & [60] \\
\hline
\end{tabular}

differential pressure, sub-micron particular filtration efficiency at $0.1 \mu \mathrm{m}$, and resistance to penetration by synthetic blood. ${ }^{[80]}$ Supplementary Table SIII shows the ASTM and ISO standards related with facial masks and ventilators. FDA has many guidelines and specific steps for the approval process. In many situations, this takes time but the pandemic can also lead to accelerated timelines for approval. ${ }^{[81,82]}$ Animal models typically precede human trials (Table IV).

\section{Government acceptance of 3D-printed parts}

Due to the rapidly spreading pandemic COVID-19, many countries are currently facing shortages on key pieces of PPEs and breathing devices for patients. Because the normal production 
Table V. Regulatory approval for 3D-printed medical projects by country.

\begin{tabular}{|c|c|c|c|c|}
\hline Country & Medical device/PPE/projects & $\begin{array}{l}\text { Government agency in } \\
\text { focus }\end{array}$ & Issues/remarks & Ref. \\
\hline USA & $\begin{array}{l}\text { Face masks/face shields/ } \\
\text { ventilator pieces }\end{array}$ & FDA & $\begin{array}{l}\text { Some concerns on if 3D-printed items can maintain } \\
\text { certain standards of protection, but they are working } \\
\text { to approve several authorized designs for mass } \\
\text { printing. }\end{array}$ & [83] \\
\hline Canada & $\begin{array}{l}\text { Face mask/face shields (Class } \\
\text { I devices) }\end{array}$ & Health Canada & $\begin{array}{l}\text { Standards must be followed and test laboratories are } \\
\text { available for free testing of devices before distribution. }\end{array}$ & [13] \\
\hline Italy & Valves and face masks & AIFA & $\begin{array}{l}\text { Still going through more testing, but COVID-19 has } \\
\text { allowed for some certifications to be bypassed. Also } \\
\text { follows EU guidelines. }\end{array}$ & {$[84,85]$} \\
\hline Spain & $\begin{array}{l}\text { Emergency Bagger/BMV } \\
\text { (Leitat1 and Leitat2) }\end{array}$ & $\begin{array}{l}\text { Spanish Agency of } \\
\text { Medicines and } \\
\text { Medical Devices }\end{array}$ & $\begin{array}{l}\text { Leitat } 1 \text { medically validated by a ventilation specialist, } \\
\text { and Leitat } 2 \text { is being produced following closer } \\
\text { guidelines of the Spanish Agency of Medicines and } \\
\text { Medical Devices and the State Pharmacological } \\
\text { Agency. Also follows the EU guidelines. }\end{array}$ & {$[84,86]$} \\
\hline UK & $\begin{array}{l}\text { Improvised masks from } \\
\text { snorkels with 3D-printed } \\
\text { connections/Visor, } \\
\text { Headband }\end{array}$ & $\begin{array}{l}\text { Medicines and } \\
\text { Healthcare Products } \\
\text { Regulatory Agency }\end{array}$ & $\begin{array}{l}\text { NIH is working on these projects due to the lack of } \\
\text { equipment currently available. Also follows the EU } \\
\text { guidelines. }\end{array}$ & {$[84,87]$} \\
\hline Germany & $\begin{array}{l}\text { Face masks and ventilator } \\
\text { pieces }\end{array}$ & BfArM & $\begin{array}{l}\text { DIN has adapted their standards to follow those of the EU } \\
\text { in this time of COVID-19. }\end{array}$ & {$[84,88]$} \\
\hline France & $\begin{array}{l}\text { Valves, syringe plungers, face } \\
\text { masks, intubation, and } \\
\text { ventilator equipment }\end{array}$ & ANSM & $\begin{array}{l}\text { Paris hospital authority set up a 3D COVID project and } \\
\text { many of the devices have been fast-tracked for } \\
\text { certification. Also follows the EU guidelines. }\end{array}$ & {$[84,89]$} \\
\hline Turkey & Face shields & $\mathrm{MOH}$ of IMMDA & $\begin{array}{l}\text { Face shields are being printed and looking for the } \\
\text { approval of certain designs. }\end{array}$ & {$[90]$} \\
\hline Belgium & Oxygen mask & FAMHP & $\begin{array}{l}\text { Currently being printed and tested for greater use in } \\
\text { Europe and the USA as well. Also follows the EU } \\
\text { guidelines. }\end{array}$ & {$[84,91]$} \\
\hline Russia & $\begin{array}{l}\text { Valves for Venturi Oxygen } \\
\text { Masks }\end{array}$ & FSBI SCEEMP & $\begin{array}{l}\text { Ministry of Health, Emergency Situations Ministry, and } \\
\text { Defense Ministry have been alerted of this capability } \\
\text { and devices will be printed when necessary. }\end{array}$ & [92] \\
\hline
\end{tabular}

and supply of these key items cannot match the unprecedented demand, many countries are turning to other means of manufacturing for these items. While these specific responses by no means represent how all countries have or will respond to this shortage, many governments are making public statements on how their country will make these necessary changes to the medical equipment while keeping safety and sterility at the forefront of their focus. Face masks/shields, Venturi valves, and other oxygen masks are some of the most sought after equipment seeking approval in a new 3D-printed form. Table V outlines how some of the highest affected countries and their government medical agencies are responding to these demands for 3D-printed equipment. Most of the designs for 3D-printed PPE and devices fall into the Class I and Class II devices. The various types of medical devices and their qualifications are shown in Supplementary Fig. S5. ${ }^{[93,94]}$ A few agencies that seem to be leading the charge in developing guidelines and approvals for these new devices are the FDA of the United States and Health Canada of Canada. Knowing that 3D-printed medical devices and PPE can give rise to concerns about compromised levels of cleanliness and protection, both countries have designed specific protocol and requirements that must be followed before approval, and production of PPE and medical devices can ensue. Both the FDA and Health Canada are working to authorize a few key designs that can be widely produced to allow for enhanced quality control. ${ }^{[13,83]}$ Like the FDA and Health Canada, the European Union (EU) has also quickly developed changes to their existing medical procedures to specifically combat the spread of COVID-19 with the help of these 3D-printed pieces of equipment. Forms and guidelines are required to be met before approval from the EU and can be given for designs and production. Harmonized standards are now available for these 3D-printed devices to follow, and some Class I devices can even make it to market with a declaration of conformity. ${ }^{[84]}$ A few countries developing 3D-printed equipment following these EU guidelines and their 
own countries agencies are Italy, Spain, Germany, UK, France, and Belgium. These countries have used the EU's guidelines to create their own independent responses with some even allowing for bypasses of certain certifications now. Countries like China, Turkey, and Russia have begun printing devices during this shortage and have notified their respective governments under each countries' specific case-by-case guidelines. ${ }^{[90,92]}$ Many of these are designs that will be approved after specific design qualifications are met and testing protocols are followed. A type "right-to-try" waiver is sometimes the most specific way to navigate the trial process giving real-time results but with accompanying risks. More of these specific devices and remarks from government authorities of some affected countries can be seen in further detail in Table V.

\section{D printing PPEs at organizations and universities}

Many groups in industry and academia has lead the way in demonstrating the value of $3 \mathrm{D}$ printing in meeting the challenges of COVID-19. A most common way that these groups have contributed include activities in producing hundreds and even thousands of PPEs (face shields, masks, and venture valves). To name a few, efforts have been reported by the University of Washington, Case Western Reserve University, University of Tennessee, Czech Technical University, Michigan State University, and Penn State University. Companies like Formlabs, Makerbot, 3D Systems, Stratasys, and Markforged are leading the way with their own machines and materials. Lastly, organizations such as America Makes, CECIMO, Department of Human Health and Services (HHS) and NIH, and the Philippines Department of Science and Technology (DOST) have organized calls and communities for the COVID-19 needs.

3D printing activities at the University of Tennesse-Knoxville (UTK) and Bataan Peninsula State University (BPSU) are summarized in Supplementary Figs. S6 and S7, respectively ${ }^{[48,95,96]}$ (see Supplementary Material).

\section{Moving forward with prototyping, limited production, and eventual mass production \\ 3D printing farms}

$3 \mathrm{D}$ printing farms are a collection of $3 \mathrm{D}$ printers in order to increase production speed. This is one effective way used by several companies, especially $3 \mathrm{D}$ printer manufacturers, to transition from prototyping to mass production. 3D print farms usually employ a customized software to manage the farm. ${ }^{[97]}$ Supplementary Figure S9 demonstrate a 3D printing farm at the Bataan Peninsula State University.

\section{Combination of $A M$ and formative manufacturing}

Our group recently published a study regarding the possibility of combining AM (3D printing) and formative manufacturing (injection molding). ${ }^{[95,96]}$ The cost and lead time for tooling/ mold fabrication will be significantly reduced when these two processes are combined. Therefore, the 3D-printed tool or die becomes a multiplier. In addition, the pellets used for production are much cheaper than plastic filament/resins being used in 3D printing. Supplementary Figure S10 shows the 3D-printed molds and injected parts demonstrated in our previous study. ${ }^{[95]}$

\section{Injection molding}

If there is a need for tens of thousands of parts, then a shift to conventional manufacturing, i.e., formative manufacturing through injection molding, could be the ideal manufacturing process.

Supplementary Figure S10 shows the plastic injection mold being used by the DOST for their face shield frames. These molds were fabricated at the Die and Mold Solution Center (DMSC) of the DOST Metals Industry Research and Development Center (MIRDC). ${ }^{[98]}$

\section{Distributed and Cooperative Additive Manufacturing network (DiCAM network)}

A new framework being coined as the Distributed and Cooperative Additive Manufacturing Network (DiCAM Network) shown in Fig. 4 is being introduced in this study. A producer may participate in a Cooperative Network if it cannot meet the desired service-level requirement of its external customers. The network would consolidate the external customers and routes an arriving external customer to one of the members. ${ }^{[99]}$ On the other hand, Distributed Manufacturing is a form of decentralized production/manufacturing which is autonomous and is near the end-user. This form of manufacturing usually makes use of information technology. This is the opposite of the traditional centralized way of manufacturing which is large in scale and usually needs long lead time and forecasting. ${ }^{[100]}$

In this framework, the process of producing goods/items/ devices will start from the need in the community or industries. Standards (either in the item/device itself or in the manufacturing process or testing procedures) will have to be considered. Government regulations for the production, distribution, use, and disposal will also have to be considered as well. File sharing communities (web) such as thingiverse and grabcad in the case of $3 \mathrm{D}$ printing will also play an important role in this framework. A local or national database of all who have 3D printers as well as the available 3D printing technologies and materials will have to be established preferably by a university or a maker community in a locality. These local players will then try to localize designs available in file-sharing communities. This DiCAM network may be tapped during National Emergencies or even during local disasters/needs.

\section{Prospects and challenges Prospects}

There is great potential in tapping the AM Technology, namely:

- Localization of production. The design, mainly the size of the item/device/equipment, may be adapted to local users (i.e., flexible and highly customizable). 


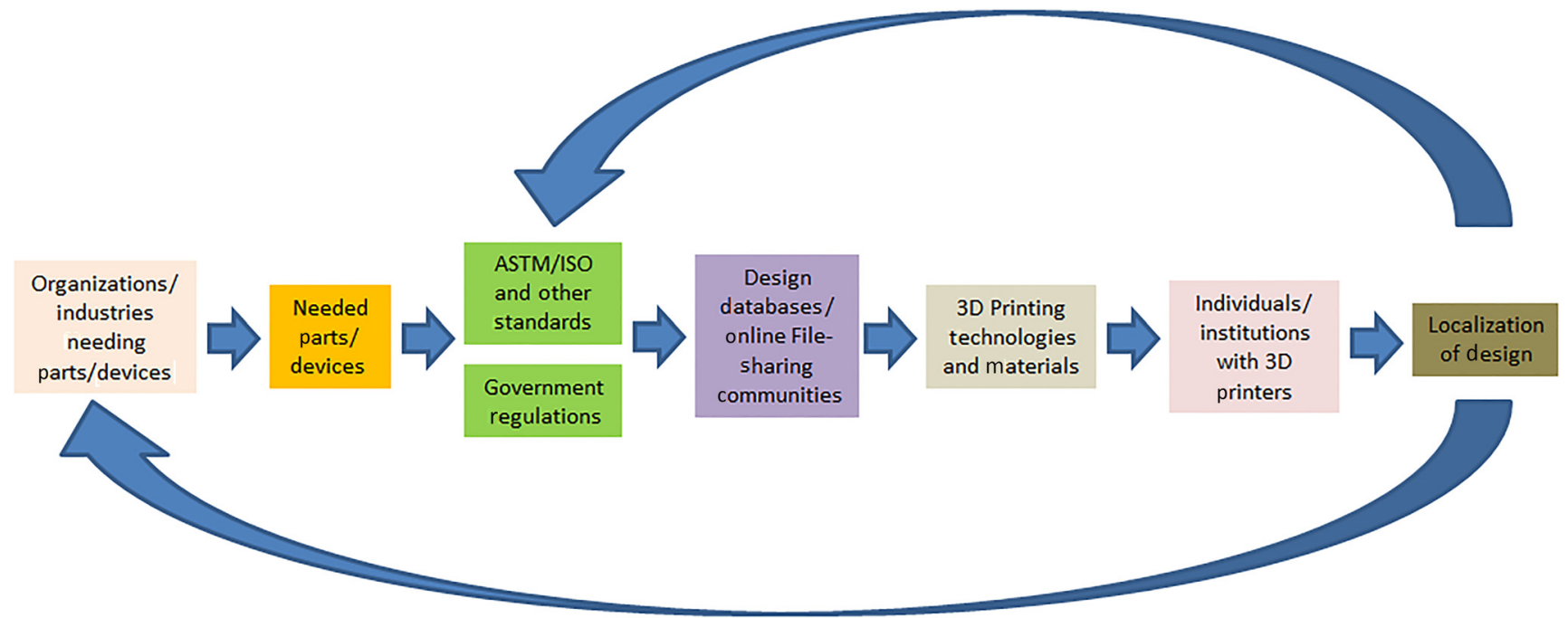

Figure 4. Framework for the DiCAM network.

- Democratization of $3 D$ printing. With the mainstreaming of $3 \mathrm{D}$ printing just like $2 \mathrm{D}$ printers and other office and household supplies, 3D printers, parts, accessories, supplies, and materials will easily be within reach.

- Advancement of $3 D$ printing technology. With many research groups doing studies on the 3D printing technology and 3D printing materials, as well as the launching of new scientific journals focusing on $3 \mathrm{D}$ printing, there is no doubt that the technology will rapidly advance, thereby being able to be applied to many different useful applications. Add to this the expiration of patents of original inventors of 3D printing technologies, making innovation faster for researchers from all corners of the globe. Competition among different manufacturers often leads to cheaper goods, and thereby we would expect cheaper, more advanced, more and user-friendly 3D printers.

- Establishment of new advanced manufacturing facilities, makerspaces, and fablabs. These facilities provide access not only to students of a particular university, but also to the community. The keyword is "access," when we provide access we empower the individual. Moreover, these facilities not only provide access to equipment and materials, but also to the expertise of the mentors and the internal/external network that comes with working in such facilities.

\section{Challenges}

With new technologies and processes come several issues, these include:

- Legal/patent issues. With 3D printing, one can easily copy/ infringe the proprietary designs by companies. This will often lead to litigations after the fact but can be deemed acceptable in emergency situations.

- Ethics. Testing of medical products usually have human involvement and thereby will need consent. Animal models may first be used but in an emergency need; the right-to-try consent or waiver is important before proceeding.

- Safety. Questions such as biocompatibility of materials used would often arise and need to be addressed if used for longterm invasive procedures. Sterilizability is a more important problem, especially if devices are reused.

- Materials testing. As mentioned in this paper, there are certain standards for the materials, processing, and testing that are needed to be considered that are specific for 3D-printed parts. The FDA may be a final arbiter but reliability will be more for long-term use (ISO and ASTM).

- Sustainability. Majority of the 3D printers worldwide use plastic filaments (i.e., FDM technology) which usually employ rafts and supports. These rafts/supports are usually being thrown away. There is a need to promote recyclability or the circular economy concept to people/organizations using 3D printers.

- Cost. Right now, manufacturing by 3D printers are still quite expensive per unit production. This can be competitive in high throughput farms and lower cost of materials (e.g., pellets instead of filaments). But their advantage in local and distributed manufacturing can be an advantage with less transport needs.

- Materials durability/robustness. The physical properties of 3D-printed parts are usually known to be intrinsically anisotropic due to their layered structure. Add to this the many different ways one can set the 3D printing parameters which would affect the mechanical and other characteristics of 3D-printed parts.

\section{Recommendations}

This prospective has given us an unprecedented picture on the $3 \mathrm{D}$ printing ecosystem and how it can be used to meet national 
and worldwide emergency needs such as a pandemic. Addressing the supply chain for PPEs, devices, and medical consumables in this pandemic has shown the importance of AM in bringing together the academic and industry communities to help the needs. Moreover, it has shown the true potential for rapid prototyping, manufacturing, and repair in real time. The main points to consider are as follows:

- AM is a method to rapidly produce objects and parts primarily using polymers or plastics, and it has shown the ability to produce fast for needs in the medical community.

- Engineers and manufacturers can rely on AM to produce prototypes that can be tested for newly designed equipment or parts in order to meet validation needs and ad hoc, animal and clinical testing.

- Collaboration with engineers, materials scientists, clinicians, and even entrepreneurs can bring about rapid adaptation to emerging situations in manufacturing.

- Understanding material properties are important for providing the needs for short- and long-term performance of the devices. The specific tensile, flexural, and compressive properties of materials will depend on the type of application. Additionally, a combination of different loading conditions as well as wear/fatigue and ageing properties will also have to be considered.

- Specific properties of materials can be improved to have good surface properties or even antiviral properties.

- AM can be used for rapid tooling and die or mold fabrication which becomes a bridge of formative manufacturing such as injection molding or thermoforming.

- Governments may consider adopting AM technologies in the production of PPEs and devices in emergency situations. This would include rapid mobilization, standardizing printing parameters, materials, and design in order to meet the minimum requirements of protection and function for the intended needs.

\section{Supplementary material}

9The supplementary material for this article can be found at https://doi.org/10.1557/mrc.2020.57.

\section{Acknowledgments}

This work is supported by the Department of Science and Technology-Philippine Council for Industry, Energy, and Emerging Technology Research and Development (DOST-PCIEERD) and Bataan Peninsula State University. The work by the students are also supported by the University of Tennessee, Center for Materials Processing and the Governor's Chair Funds.

\section{References}

1. U.S. Food and Drug Administration (FDA): Medical devices and the COVID-19 (coronavirus) pandemic. https://www.fda.gov/medicaldevices/emergency-situations-medical-devices/medical-devices-andcovid-19-coronavirus-pandemic (accessed April 21, 2020).
2. Nebraska Medicine: Personal protective equipment for COVID-19 https://www.nebraskamed.com/sites/default/files/documents/covid-19/ PPE_infographic.pdf (accessed April 21, 2020).

3. S. Bhadra, Y.S. Jiang, M.R. Kumar, R.F. Johnson, L.E. Hensley, and A.D. Ellington: Real-time sequence-validated loop-mediated isothermal amplification assays for detection of Middle East respiratory syndrome coronavirus (MERS-CoV). PLoS One 10, 1-21 (2015).

4. J.F.W. Chan, G.K.Y. Choi, A.K.L. Tsang, K.M. Tee, H.Y. Lam, C.C.Y. Yip, K.K.W. To, V.C.C. Cheng, M.L. Yeung, S.K.P. Lau, P.C.Y. Woo, K.H. Chan, B.S.F. Tang, and K.Y. Yuen: Development and evaluation of novel real-time reverse transcription-PCR assays with locked nucleic acid probes targeting leader sequences of human-pathogenic coronaviruses. J. Clin. Microbiol. 53, 27222726 (2015).

5. P. Zhai, Y. Ding, X. Wu, J. Long, Y. Zhong, and Y. Li: The epidemiology, diagnosis and treatment of COVID-19. Int. J. Antimicrob. Agents 105955 (2020).doi:10.1016/j.ijantimicag.2020.105955

6. CDC: Interim guidelines for collecting, handling, and testing clinical specimens from persons for coronavirus disease 2019 (COVID-19). https://www.cdc.gov/coronavirus/2019-ncov/lab/guidelines-clinicalspecimens.html (accessed April 21, 2020).

7. Rhode Island Department of Health: 2019-Novel coronavirus (Covid-19) specimen collection kit instructions. https://health.ri.gov/publications/ instructions/COVID-19-Specimen-Collection-Kit.pdf

8. The Philippine - American Academy of Science \& Engineering: The need for a low-cost ventilator now. http://paase.org/downloads/PAASE Bulletin 14.pdf (accessed May 2, 2020).

9. R.L. Chatburn and E. Mireles-Cabodevila: Basic principles of ventilator design. In Principles and Practice of Mechanical Ventilation, 3rd ed. edited by M.J. Tobin (Mc Graw-Hill, New York, NY, 2013).

10. A. Yartsev: Basic components of a mechanical ventilator, 2018. https:// derangedphysiology.com/main/cicm-primary-exam/required-reading/ respiratory-system/Chapter 501/basic-components-mechanical (accessed April 21, 2020).

11. R.J. Roberge: Face shields for infection control: a review. J. Occup. Environ. Hyg. 13, 239-246 (2016).

12. W. W. Grainger, Inc.: Faceshield protection. https://www.grainger.com/ content/qt-face-shield-protection-373 (accessed April 21, 2020).

13. Government of Canada: 3D printing and other manufacturing of personal protective equipment in response to COVID-19, 2020. https://www.canada.ca/en/health-canada/services/drugs-health-products/medicaldevices/covid-19-unconventional-manufacturing-personal-protectiveequipment.html (accessed April 21, 2020).

14. T.N.A. Press: Characteristics of respirators and medical masks. In The National Academics of Sciences Engineering Medicine, no. 2006 (The National Academies Press, Washington, DC, 2006) pp. 22-41.

15. B. Henneberry: How to make N95 Masks, 2020. https://www.thomasnet. com/articles/plant-facility-equipment/how-to-make-n95-masks/ (accessed April 21, 2020).

16. B. Henneberry: How surgical masks are made, 2020. https://www.thomasnet.com/articles/other/how-surgical-masks-are-made/ (accessed April 21, 2020).

17. Thomas: How to make protective gowns for Coronavirus/COVID-19. https://www.thomasnet.com/articles/other/how-to-make-protectivegowns-for-coronavirus-covid-19/ (accessed April 21, 2020).

18. E. Irzmańska and A. Brochocka: Modified polymer materials for use in selected personal protective equipment products. Autex Res. J. 17, 35-47 (2017).

19. S.L. Farrier, J.N. Farrier, and A.S.M. Gilmour: Eye safety in operative dentistry: a study in general dental practice. Br. Dent. J. 200, 218-223 (2006).

20. V. Roberts: To PAPR or not to PAPR? Can. J. Respir. Ther. 50, 87-90 (2014).

21. Thomas: What are PAPR (powered air purifying respirators)? https:// www.thomasnet.com/articles/plant-facility-equipment/what-are-paprpowered-air-purifying-respirators/ (accessed April 21, 2020).

22. C.-NPPTL: Respiratory protection infographics, 2020, The National Personal Protective Technology Laboratory (NPPTL), https://www.cdc. gov/niosh/nppt//Respiratorlnfographics.html. 
23. C.NPPTL: NIOSH-approved particulate filtering facepiece respirators, 2018. https://www.cdc.gov/niosh/nppt//topics/respirators/disp_part/ (accessed April 21, 2020).

24. Board on Health Sciences Policy; Institute of Medicine: Defining PAPRs and current standards. In The Use and Effectiveness of Powered Air Purifying Respirators in Health Care: Workshop Summary (National Academies Press, Washington, DC, 2015)

25. J.R.C. Dizon, A.H. Espera, Q. Chen, and R.C. Advincula: Mechanical characterization of 3D-printed polymers. Addit. Manuf. 20, 44-67 (2018).

26. ISO/TC 261 Additive Manufacturing: ISO/ASTM 52915:2020 Specification for additive manufacturing file format (AMF) Version 1.2, 2020. https://www.iso.org/standard/74640.html (accessed April 21, 2020).

27. A.C. De Leon, Q. Chen, N.B. Palaganas, J.O. Palaganas, J. Manapat, and R.C. Advincula: High performance polymer nanocomposites for additive manufacturing applications. React. Funct. Polym. 103, 141-155 (2016).

28. A.D. Valino, J.R.C. Dizon, A.H. Espera, Q. Chen, J. Messman, and R.C. Advincula: Advances in 3D printing of thermoplastic polymer composites and nanocomposites. Prog. Polym. Sci. 98, 101162 (2019).

29. 3D Printing Industry: 3D printing processes. https://3dprintingindustry. com/3d-printing-basics-free-beginners-guide\#04-processes (accessed April 21, 2020)

30. L.D. Tijing, J.R.C. Dizon, I. Ibrahim, A.R.N. Nisay, H.K. Shon, and R.C. Advincula: 3D printing for membrane separation, desalination and water treatment. Appl. Mater. Today 18, 100486 (2020).

31. A.H. Espera, J.R.C. Dizon, Q. Chen, and R.C. Advincula: 3D-printing and advanced manufacturing for electronics. Prog. Addit. Manuf., 4, 245267 (2019)

32. J.R.C. Dizon, Q. Chen, A.D. Valino, and R.C. Advincula: Thermomechanical and swelling properties of three-dimensional-printed poly (ethylene glycol) diacrylate/silica nanocomposites. MRS Commun. 9, 209-217 (2019)

33. J.Z. Manapat, Q. Chen, P. Ye, and R.C. Advincula: 3D printing of polymer nanocomposites via stereolithography. Macromol. Mater. Eng. 302, 1$13(2017)$

34. A.H. Espera, A.D. Valino, J.O. Palaganas, L. Souza, Q. Chen, and R.C. Advincula: 3D printing of a robust polyamide-12-carbon black composite via selective laser sintering: thermal and electrical conductivity. Macromol. Mater. Eng. 304, 1-8 (2019)

35. Q. Chen, J. Zhao, J. Ren, L. Rong, P.F. Cao, and R.C. Advincula: 3D printed multifunctional, hyperelastic silicone rubber foam. Adv. Funct. Mater. 29, 1-9 (2019)

36. Q. Chen, J.D. Mangadlao, J.D. Wallat, A. Christopher, C. De Leon, J.K. Pokorski, and R.C. Advincula: 3D printing biocompatible polyurethane/ poly (lactic acid)/graphene oxide nanocomposites: anisotropic properties, ACS Appl. Mater. Interfaces 2017, 9, 4, 4015-4023

37. National Institutes of Health: COVID-19 supply chain response. https:// 3dprint.nih.gov/collections/covid-19-response (accessed April 21, 2020)

38. U.S. Food and Drug Administration: FAQs on 3D printing of medical devices, accessories, components, and parts during the COVID-19 pandemic. https://www.fda.gov/medical-devices/3d-printing-medicaldevices/faqs-3d-printing-medical-devices-accessories-componentsand-parts-during-covid-19-pandemic (accessed April 21, 2020).

39. C. Richburg: Stopgap surgical facemask (SFM), 2020. https://3dprint. nih.gov/discover/3dpx-013429 (accessed April 21, 2020).

40. D. Richardson, S. Zaugg, and C. Zaugg: The Montana Mask, 2020. https://www.makethemasks.com/ (accessed April 21, 2020).

41. MUSC Medical University of South Carolina: SAFE Cartridge Systems and Mask. https://web.musc.edu/innovation/covid-19-innovation/safecartridge-system-and-masks (accessed April 21, 2020).

42. Barrow Neurological Institute: 3D-printed N95 replacement mask, 2020. https://www.barrowneuro.org/get-to-know-barrow/barrow-innovationcenter-2/3d-printed-n95-mask/ (accessed April 21, 2020).

43. Rowan University: Re-usable 3D-printed face mask. https://engineering. rowan.edu/research-centers/mask/index.html (accessed April 21, 2020).

44. 3Dwasp: My face mask. https://www.3dwasp.com/en/3d-printed-maskfrom-3d-scanning/ (accessed April 21, 2020).
45. D. Provenzano, Y.J. Rao, K. Mitic, S.N. Obaid, D. Pierce, J. Huckenpahler, J. Berger, S. Goyal, and M.H. Loew: Rapid prototyping of reusable 3D-printed N95 equivalent respirators at the George Washington University, March, 2020, pp. 1-9.

46. Copper3D: Hack the pandemic. https://copper3d.com/hackthepandemic/ (accessed April 21, 2020).

47. CIIRC: CIIRC CTU anti-COVID-19. https://www.ciirc.cvut.cz/covid-2/ (accessed April 21, 2020).

48. BRND University of Technology: COVID-19 Protection Halfmask BUT-H1. https://www.vutbr.cz/en/but/f19528/d197642 (accessed April 21, 2020)

49. E. Livingston, A. Desai, and M. Berkwits: Sourcing personal protective equipment during the COVID-19 pandemic. JAMA 323, 1912-1914 (2020).

50. Creality: Makers guide-3D printed face mask. https://www.creality.com/ info/makers-guide-3d-printed-face-mask-no-worries-on-mask-shortage-and-virus-infection-i00248i1.html (accessed April 21, 2020).

51. Prusa3D: 3D printed face shields for medics and professionals. https:// www.prusa3d.com/covid19/ (accessed April 21, 2020).

52. Oxvent: OxVent. https://oxvent.org/ (accessed April 21, 2020).

53. MedRxiv: Mechanical ventilator milano (MVM). https://www.medrxiv. org/content/10.1101/2020.03.24.20042234v1 (accessed April 21, 2020).

54. A. Mohsen Al Husseini, H. Ju Lee, J. Negrete, S. Powelson, A. Tepper Servi, and A.H. Slocum: Design and prototyping of a low-cost portable mechanical ventilator. J. Med. Dev. Trans. ASME 4, 1-1 (2010).

55. VentilAid: VentilAid. https://www.ventilaid.org/ (accessed April 21, 2020).

56. MIT Emergency Ventilator: E-VENT. https://e-vent.mit.edu/ (accessed April 21, 2020).

57. M. Burns: Tesla shows how it's building ventilators with car parts, 2020 . https://techcrunch.com/2020/04/05/ tesla-shows-how-its-building-ventilators-with-car-parts/ (accessed April 21, 2020)

58. M. Petch: 3D Printing community reponds to COVID-19 and coronavirus resources, 2020. https://3dprintingindustry.com/news/3d-printing-community-responds-to-covid-19-and-coronavirus-resources-169143/ (accessed April 21, 2020).

59. C. Graham: Johns Hopkins engineers develop 3D-printed ventilator splitters, 2020. https://hub.jhu.edu/2020/04/02/3d-printed-ventilator-splitters-for-covid-19/ (accessed April 21, 2020).

60. T. Boissonneault: WinSun deploys 3D printed isolation wards for coronavirus medical staff, 2020. https://www.3dprintingmedia.network/ winsun-3d-printed-isolation-wards-coronavirus-medical-workers/ (accessed April 21, 2020)

61. 3D Systems: COVID-19 call to action, 2020. https://www.3dsystems com/covid-19-response (accessed April 21, 2020).

62. Formlabs: 3D printed test swabs, 2020. https://formlabs.com/ covid-19-response/covid-test-swabs/ (accessed April 21, 2020).

63. Carbon3D: Carbon COVID-19 response, 2020. https://www.carbon3d com/covid19/ (accessed April 21, 2020).

64. F.W. Billmeyer: Textbook of Polymer Science, Vol. 2. (Wiley, New York, NY, 1984)

65. C.G. Tadmor and Z. and Gogos: Principles of Polymer Processing (John Wiley \& Sons, New Jersey, 2013).

66. A.A. Konta, M. García-Piña, and D.R. Serrano: Personalised 3D printed medicines: which techniques and polymers are more successful? Bioengineering 4, 79 (2017).

67. Q. Chen, P. Cao, and R.C. Advincula: Mechanically robust, ultraelastic hierarchical foam with tunable properties via 3D printing. Adv. Funct. Mater. 28, 1800631 (2018).

68. P. Wei, H. Leng, Q. Chen, R.C. Advincula, and E.B. Pentzer: Reprocessable 3D-printed conductive elastomeric composite foams for strain and gas sensing. ACS Appl. Polym. Mater. 1, 885-892 (2019).

69. J.V. Gulmine, P.R. Janissek, L. Akcelrud, and H.M. Heise: Polyethylene characterization by FTIR. Polym. Test 21, 557-563 (2002).

70. F.J. Padden and H.D. Keith: Spherulitic crystallization in polypropylene. J. Appl. Phys. 30, 1479-1484 (1959).

71. D.E. Winkler: Mechanism of polyvinyl chloride degradation and stabilization. J. Polym. Sci., 35, 3-16 (1959). 
72. F. Yang, Y. Ou, and Z. Yu: Polyamide 6/silica nanocomposites prepared by in situ polymerization. J. Appl. Polym. Sci. 69, 355-361 (1998).

73. J.D. Keitz, J.W. Barlow, and D.R. Paul: Polycarbonate blends with styrene/acrylonitrile copolymers. J. Appl. Polym. Sci. 29, 3131-3145 (1984).

74. R.K. Kulkarni, E.G. Moore, A.F. Hegyeli, and F. Leonard: Biodegradable poly(lactic acid) polymers. J. Biomed. Mater. Res. 5, 169-181 (1971).

75. A. Kausar: Polyurethane/epoxy interpenetrating polymer network, pp. 116, DOI: $10.5772 / 67678$

76. E.L. Warrick, O.R. Pierce, K.E. Polmanteer, and J.C. Saam: Silicone elastomer developments 1967-1977. Rubber Chem. Technol. 52, 437-525 (1979).

77. ASTM: Standard test method for determining the initial efficiency of materials used in medical face masks to penetration by particulates using latex spheres, vol. 03, no. Reapproved, 2010, pp. 1-8.

78. ASTM: Standard test method for evaluating the bacterial filtration efficiency (BFE) of medical face mask materials using a biological aerosol of Staphylococcus aureus, vol. I, no. June, 2001, pp. 1-5.

79. ASTM: Standard test method for resistance of medical face masks to penetration by synthetic blood (horizontal projection of fixed volume at a known velocity), 2007, pp. 1-18.

80. ASTM: Standard specification for performance of materials used in medical face masks. Test 11, 19-21 (2005).

81. ASTM: ASRM standards \& COVID-19. https://www.astm.org/COVID-19/ (accessed May 2, 2020).

82. ISO: COVID-19 response: freely available ISO standards. https://www. iso.org/covid19 (accessed May 2, 2020).

83. N.P. Taylor: FDA outlines role for $3 \mathrm{D}$ printing in coronavirus response, with some caution, 2020. https://www.medtechdive.com/news/fdaweighs-in-on-3d-printing-coronavirus-response-with-some-caution/ 575001/ (accessed April 21, 2020).

84. European Commission: Conformity assessment procedures for 3D printing and $3 \mathrm{D}$ printed products to be used in a medical context for COVID-19. https://ec.europa.eu/docsroom/documents/40562 (accessed April 21, 2020).

85. A. Feldman: Meet the Italian engineers 3D-printing respirator parts for free to help keep coronavirus patients alive, 2020. https://www.forbes. com/sites/amyfeldman/2020/03/19/talking-with-the-italian-engineerswho-3d-printed-respirator-parts-for-hospitals-with-coronavirus-patients-for-free/\#21109f7d78f1 (accessed April 21, 2020).

86. D. Sher: The mechanical BVM (bag valve mask) can be used as an emergency ventilation device, 2020. https://www.3dprintingmedia.network/ leitat-presents-first-medically-validated-industrialized-3d-printed-ventilator/ (accessed April 21, 2020).

87. S. Marsh: NHS staff making masks from snorkels amid PPE shortages, 2020. https://www.theguardian.com/society/2020/apr/01/nhs-staffmaking-masks-from-snorkels-amid-ppe-shortages (accessed April 21, 2020).

88. D. Tschammler, J. Grieb, and S. Rau: COVID-19 legal implications for pharmaceutical and medical device companies in Germany, 2020. https://www.mwe.com/insights/covid-19-legal-implications-forpharmaceutical-and-medical-device-companies-in-germany/

89. T. Star: Covid-19: Paris hospitals turn to 3D printing to cover shortfalls. https://www.thestar.com.my/tech/tech-news/2020/04/03/ covid-19-paris-hospitals-turn-to-3d-printing-to-cover-shortfalls (accessed April 21, 2020).

90. Xinhua: Feature: Turkish volunteers produce face shields with 3D printers amid COVID-19 outbreak, 2020. http://www.xinhuanet.com/english/ 2020-04/06/c_138949892.htm (accessed April 21 2020).

91. M. Meisenzahl: This 3D-printed oxygen mask was designed to help with a lack of ventilators for coronavirus patients, 2020. https://www. businessinsider.com/3d-printed-oxygen-mask-ventilators-covid-19-2020-4 (accessed April 21, 2020).

92. Powermag: Rosatom groups help medical workers battle coronavirus, 2020. https://www.powermag.com/rosatom-groups-help-medical-workers-battle-coronavirus/ (accessed April 21, 2020).

93. BMP Medical: What's the difference between the FDA medical device classes? 2020. http://www.bmpmedical.com/blog/whats-differencefda-medical-device-classes-2/ (accessed April 21, 2020).
94. U.S. Food \& Durg Administration: Product classification. https://www. accessdata.fda.gov/scripts/cdrh/cfdocs/cfpcd/classification.cfm? start_search $=1 \&$ Submission_Type_ID=\&DeviceName=mask\&ProductCode $=\&$ DeviceClass $=\&$ ThirdParty $=\&$ Panel $=\&$ RegulationNumber $=\& I \mathrm{mp}-$ lant_Flag=\&Life_Sustain_Support_Flag=\&PAGENUM=10\&sortcolum$\mathrm{n}=\mathrm{De}$ (accessed April 21, 2020).

95. J.R.C. Dizon, A.D. Valino, L.R. Souza, A.H. Espera, Q. Chen, and R.C. Advincula: Three-dimensional-printed molds and materials for injection molding and rapid tooling applications. MRS Commun. 9, 1267-1283 (2019).

96. J.R.C. Dizon, A.D. Valino, L.R. Souza, A.H. Espera, Q. Chen, and R.C. Advincula: 3D printed injection molds using various $3 \mathrm{D}$ printing technologies. Mater. Sci. Forum (2020) ISSN: 1662-9752, Vol. 1005, pp 150-156.

97. Formlabs: How a 3D printer farm can help your business, 2017. https:// forlabs.com/blog/3d-print-farm-business-benefits/ (accessed April 30, 2020).

98. Republic of the Philippines, Metals Industry Research and Development Center, Department of Science and Techology: Face shield for COVID-19 frontliners: now mass-produced by the DOST-MIRDC, 2020. http://www. mirdc.dost.gov.ph/2-uncategorised/201-face-shields-for-covid-19frontliners-now-mass-produced-by-the-dost-mirdc (accessed April 26, 2020).

99. B. Hosseini and B. Tan: Modelling and analysis of a cooperative production network, International Journal of Production Research, vol. 57, 2019, pp. 6665-6686, https://doi.org/10.1080/00207543.2019.1571254.

100.J.S. Srai, M. Kumar, G. Graham, W. Phillips, J. Tooze, S. Ford, P. Beecher, B. Raj, M. Gregory, M.K. Tiwari, B. Ravi, A. Neely, R. Shankar, F. Charnley, and A. Tiwari: Distributed manufacturing: scope, challenges and opportunities. Int. J. Prod. Res. 54, 6917-6935 (2016). 